\title{
1. Transnational business governance interactions, regulatory quality and marginalized actors: An introduction
}

\author{
Stepan Wood, Burkard Eberlein, \\ Errol Meidinger, Rebecca Schmidt \\ and Kenneth W. Abbott
}

\subsection{INTRODUCTION}

Powerful actors including major states and corporations frequently exploit gaps, overlaps and conflicts in global governance to shape rules and decisions in their favour or evade regulation. They steer interactions amongst governance actors and institutions, creating inter-regime conflicts, exploiting the fragmentation of international law, orchestrating intermediaries, shopping for favourable fora and creating new ones (Raustiala and Victor 2004; Alter and Meunier 2009; Gehring and Oberthür 2009; Abbott et al. 2015; Blome et al. 2016). As important as it is to understand these manipulations, this book investigates the obverse: the circumstances in which governance interactions can be harnessed to advance the interests of marginalized actors and improve the quality of transnational regulation.

This introductory chapter proceeds as follows. In Part 2 we justify our focus on transnational business governance interactions (TBGIs). In Part 3 we turn to our central question when and how TBGIs can be harnessed to advance marginalized interests and enhance regulatory quality. We ask this question at three levels: regulatory capacities, outputs and outcomes. The first dimension, regulatory capacities, is drawn from the literature on regulation and includes symbolic and material resources along with capacities to learn and adapt. The second and third dimensions, regulatory outputs and outcomes, are drawn from the literature on regime effectiveness and include regulatory standards, institutional design features, regulatory synergies and uptake. The book explores whether and in what circumstances TBGIs can be steered to enhance 
transnational regulatory capacities, outputs and outcomes in general, and for marginalized actors in particular. Part 4 presents the plan of the book and summarizes the chapters.

\subsection{TRANSNATIONAL BUSINESS GOVERNANCE INTERACTIONS}

We coined the term transnational business governance interactions (TBGIs) to describe the interactive dynamics of transnational regulation, and proposed a framework to analyse these dynamics (Eberlein et al. 2014; Wood et al. 2015). We can summarize the concept by way of an example. In the 1980s, civil society groups in developed countries pressured governments and industry to combat tropical deforestation. In the 1990s, frustrated by states' failure to conclude a global forest treaty or to control deforestation, a coalition of civil society and business actors created the non-state Forest Stewardship Council (FSC) to set international standards for sustainable forestry and certify companies' compliance with those standards. Big retailers signed on, often in response to NGO threats to their brands, and FSC-certified forests and products multiplied. Forest owners and industry groups soon created their own competing certification schemes (Cashore et al. 2004). There is some evidence that this competition raised forest management standards and improved the governance of certification schemes (Overdevest 2010). Yet there is also evidence that upward convergence is superficial, masking persistent differences in transparency, accountability, rigour and effectiveness (Fransen 2011). These schemes also interact with national and international law in complicated ways. It is unclear, for example, what impact recent legality verification laws will have on them (Bartley 2014).

Comparable developments are occurring in many other economic sectors and issue areas. Transnational non-state governance actors and institutions interact with each other and with state-based actors and institutions at multiple spatial and temporal scales, with poorly understood effects on regulatory capacity, social and environmental standards, and marginalized actors.

The TBGI concept provides a common starting point for investigating these phenomena. Governance denotes deliberate efforts to change target actors' behaviour in furtherance of collective goals via norms, monitoring and enforcement (Black 2002, p. 170; Wood et al. 2015, pp. 337-8). Governance so understood is synonymous with 'regulation' or 'regulatory governance'. It is not restricted to states, international organizations 
or their formal governmental apparatus, but includes non-state and hybrid institutions created by a variety of actors and employing diverse regulatory techniques (Hood et al. 2001, p. 25; Scott 2004, pp. 161-6).

We focus on the governance of business, whether conducted by private firms or state-owned enterprises. The globalization of business generates some of the most serious and widespread contemporary governance challenges. The TBGI research agenda is, however, ripe for extension to other governance domains, such as health, education, migration, crime and security.

Transnational governance is governance in which non-state actors or institutions assert or exercise authority in the performance of one or more components of regulatory governance across national borders. These components include agenda-setting, norm formation, implementation, monitoring, enforcement and evaluation (ANIMEE). Actors and institutions have authority when relevant audiences perceive them as appropriately engaged in a regulatory task and their decisions as worthy of respect. But transnational governance is as much about the assertion and contestation of authority as about its exercise; our definition therefore includes asserted — not just accepted — authority.

We follow a rich vein of scholarship on transnational relations (Keohane and Nye 1971; Risse-Kappen 1995; Keck and Sikkink 1998), transnational law (Jessup 1956; Likosky 2002; Calliess and Zumbansen 2010; Halliday and Shaffer 2015) and global legal pluralism (Tamanaha 2001; Twining 2009; Berman 2012). Yet these literatures tend to focus on the emergence, operation, legitimacy or effectiveness of individual programs or regimes rather than their interactions with one another (Cutler et al. 1999; Dingwerth 2007; Hale and Held 2011). To the extent they consider interactions, it is usually between non-state and state regulation (Scott et al. 2011).

We also draw on the literatures on regulatory interactions (Hahn and Noll 1983), regulatory competition (Esty and Geradin 2001), international law fragmentation (M. A. Young 2012; Andenas and Bjorge 2015), interactive federalism (Schapiro 2006), interactive governance (Kooiman 2003; Edelenbos and van Meerkerk 2016), multilevel governance (Hooghe and Marks 2001; Bache and Flinders 2004), institutional interplay (Oberthür and Gehring 2006; Oberthür and Stokke 2011) and regime complexity (Raustiala and Victor 2004). But the TBGI agenda is distinctive in examining interactions amongst non-state actors and institutions in addition to interactions between state and non-state regulation, or within state regulation.

Finally, interactions are the mutual actions and reactions of governance actors, norms, institutions and systems. They can be deliberate or 
unintended, symmetrical or asymmetrical, cooperative or conflictual, orderly or chaotic. They engage agency (interactions amongst the makers, targets, interpreters, enforcers and beneficiaries of transnational regulatory governance) and social structure (interactions amongst transnational rules, principles, standards, programs, regimes, discourses, networks, technologies, legal orders and social systems). Interaction is neither desirable nor undesirable per se; it is inherent in all governance (Kooiman 2003).

Governance interactions occur and can be studied at various scales. At a micro scale, individual actors or norms interact within a single governance organization, program or jurisdiction. At a meso scale, governance initiatives or jurisdictions interact within regimes or organizational fields, while regimes, fields and discourses shape actors and norms. At a macro scale, regimes or fields interact within complexes or systems, and complexes or systems interact with one another (see Table 1.2).

Like early research into interactions amongst intergovernmental institutions (O. R. Young 2002), research into transnational governance interactions has reached a point where the lack of common concepts and data hinders the emergence of shared knowledge. We developed the TBGI analytical framework in response to this problem (Eberlein et al. 2014). The framework provides common definitions of central concepts and enables researchers to identify knowledge gaps, prioritize research and compare results. The framework disaggregates regulatory governance into the six components mentioned above: agenda-setting, norm formation, implementation, monitoring and information-gathering, enforcement, and evaluation and review. Interactions can occur within or between any of these components. The framework also poses six questions that researchers can ask about interactions in relation to each component: who or what interacts; what drives interaction; what are the mechanisms and pathways of interaction; what is the character of interaction; what are its effects; and how does interaction change over time? The framework thus produces a six-by-six matrix, which we apply to the chapters of this book in Table 1.1 (Eberlein et al. 2014; Wood et al. 2015).

The framework recognizes that interaction can involve heterogeneous entities (such as individuals, organizations, norms, discourses or systems) and often crosses organizational and spatial scales. The same actors can regulate while being regulated (Braithwaite and Drahos 2000, p. 10). The framework also acknowledges that actors and social structures co-evolve, interaction is both a cause and an effect, and it has diverse forms, pathways and causal mechanisms (Wood et al. 2015). In short, the TBGI framework is not monolithic or totalizing but promotes mutual intelligibility while accommodating heterogeneity and complexity. 
A common analytical framework is only a starting point. Researchers must also theorize the interactive dynamics of transnational business governance. That is where this book comes in. It provides an integrative account of TBGIs that gains strength from a range of disciplines, theories and methods. The book draws on scholarly literatures in law, business, political science, sociology, environmental studies and other fields. Several of the contributors work across disciplines. Three (Bach, Carodenuto and Wood) have also been transnational business governance practitioners.

\subsection{ENHANCING REGULATORY QUALITY AND ADVANCING MARGINALIZED ACTORS}

The goal of this book is to generate insights into whether and how TBGIs, in all their variety, can be harnessed to enhance the quality of transnational regulation and advance the interests of marginalized actors. The chapters explore questions such as: which interactive strategies hold promise and who can use them (Verbruggen and Havinga, Chapter 2; Paiement, Chapter 11; Wood, Chapter 16)? Should the focus be on entrepreneurial individuals who spread regulatory models and norms (Meidinger, Chapter 3; Oman, Chapter 15); social networks (Auld and Renckens, Chapter 6; Henriksen and Seabrooke, Chapter 8); or isomorphic pressures (Gao and Chen, Chapter 13)? Why do TBGIs emerge, multiply and persist in some cases, while they stagnate, dwindle or fail to emerge in others (Westerwinter, Chapter 7; Winn, Chapter 5)? How do discursive and economic structures enable or constrain interactions (Casey, Chapter 9; Foley, Chapter 14)? How do various mechanisms and pathways of interaction operate (Bach, Chapter 12; Carodenuto and Cashore, Chapter 10; Schmidt, Chapter 4)?

Both regulatory quality and marginalized actors are contested concepts. We aim to specify them in ways that can attract relatively broad agreement while leaving open points of deep disagreement. We start with regulatory quality. We suggest assessing the relations between TBGIs and regulatory quality in terms of regulatory outputs and outcomes. We argue that their relations should also be assessed in terms of regulatory capacities - a factor overlooked by the literature on regulatory quality. We then define marginalized actors and suggest assessing their relations with TBGIs in the same terms: regulatory capacities, outputs and outcomes. Finally, we consider linkages and tensions between improving regulatory quality and advancing marginalized actors. 


\subsubsection{Regulatory Quality}

The lament that no two definitions of regulatory quality coincide rings as true today as it did two decades ago (Gunningham et al. 1998, p. 25). Certain elements are nonetheless common to most accounts.

Effectiveness at achieving policy goals is a widely accepted element of regulatory quality, but there is disagreement whether the goal should be social and environmental improvement (Gunningham et al. 1998, p. 26) or ease of doing business (World Bank 2016; European Commission 2017). If the former, the emphasis is on increasing regulatory scope and ambition; if the latter, on reducing regulatory burdens (Pelkmans et al. 2000; Brown and Scott 2011). This book is in the former camp.

Efficiency, in many accounts, is the decisive element. Regulatory quality is a matter of optimizing regulatory benefits and burdens. Efficiency demands that regulatory goals be set at levels that maximize net benefits to society and that regulatory instruments be selected to achieve those goals at minimum cost (OECD 1995, 2005). Efficiency also requires advance assessment of costs, benefits, risks and impacts, as well as regular review and revision (OECD 1995; Ogus 1995; European Commission 2002). Assessments should consider all possible regulatory goals, instruments and actors (European Commission 2001; Brown and Scott 2011), as well as distributive consequences (OECD 1995; Baldwin and Cave 1999). Distributive equity is an independent criterion in some accounts (Gunningham et al. 1998, p. 26), but we do not include it here as it is central to our second theme, advancing marginalized actors.

Third, most accounts of regulatory quality emphasize responsiveness. Responsive regulation employs a flexible, pluralistic and complementary mix of actors, strategies and tools. It is tailored to variation in problem characteristics, industry structures, regulatory institutions, and actors' incentives and motivations (Ayres and Braithwaite 1992; Osborne and Gaebler 1992; Baldwin and Black 2008). It is also comprehensive, matching the scope of the problem (World Bank 2016).

Transparency, accountability and participation round out most recipes for regulatory quality. Transparency holds that regulation and regulatory processes should be clear, coherent, consistent, comprehensible and accessible (OECD 1995; Labory and Malgarini 2000). In some formulations, regulation should also be simple and practical (European Commission 2001; OECD 2005). Accountability requires regulators to justify their actions to, and submit to the scrutiny of, the general public or narrower constituencies of interested and affected parties (Radaelli and De Francesco 2007, p. 33; Alemanno 2015). Accountability and 
transparency are often combined with proportionality, due process and respect for the rule of law (OECD 1995).

Finally, participation means that all interested parties should have the opportunity to participate in regulatory governance processes (Lobel 2004). Broad and effective participation enhances regulation's legitimacy; expands the knowledge, experience, expertise and perspectives brought to bear on problems; helps identify unintended consequences; acts as a quality control check; and fosters compliance (OECD 1995). That said, the form and degree of participation thought to be necessary vary greatly, from mere notice and comment to joint decision-making.

Effectiveness, efficiency, responsiveness, transparency, accountability and participation are all subjects of ongoing debate. The chapters address them in different ways and to differing degrees. They devote more attention to effectiveness, transparency, accountability and participation than to efficiency or responsiveness.

\subsubsection{Regulatory Outputs, Outcomes and Impacts}

In the 1960s David Easton highlighted the need to distinguish between outputs, outcomes and impacts when investigating the consequences of political systems (Easton 1965). Put briefly, political systems produce outputs (regulations and other policy instruments) which lead to outcomes (changes in the behaviour, values or perceptions of regulatory targets) which in turn have impacts on social, economic, environmental or other conditions. International relations scholars have applied this schema to the effectiveness of international regimes (Underdal and Young 2004). We suggest applying it to all the dimensions of regulatory quality.

Outputs are relatively easy to assess. Outcomes can be tricky, and impacts even more so due to the multiplicity of forces, complexity of causal relations, diversity of contexts, pervasiveness of uncertainty and difficulty of specifying ideal results and no-regulation counterfactuals (O. R. Young 2017, pp. 28, 47). In addition, successful outputs and outcomes are no guarantee of progress in solving the targeted problems (ibid.). Thus, while impacts are our ultimate interest, we focus on regulatory outputs and, to a lesser extent, outcomes.

The outputs we emphasize are institutional designs and regulatory standards. Institutional designs include the structure and composition of decision-making organs and the rules and procedures by which they operate. Institutional designs can be more or less efficient, effective, responsive, transparent, accountable or participatory. Analysing institutional designs as outputs might seem odd: they seem more like inputs, shaping the 
production of regulatory outputs. But institutional designs are also outputs insofar as actors interact with one another and with existing institutions to design or redesign regulatory institutions. We are interested in how TBGIs can be steered to improve the design of regulatory institutions.

Regulatory standards include the rules, norms, guidelines, decisions and programs that regulatory institutions promulgate with a view to influencing the conduct of regulated actors. These are typically articulated at the norm formation stage, but also affect other stages (for example, best practice guidance for rule implementation and auditor competence requirements). We focus on the ambition and scope of standards. Standards can be more or less effective, efficient, responsive or transparent and can foster or hinder accountability and participation. We want to know whether TBGIs can be harnessed to increase the ambition and scope of regulatory standards. We are likewise interested in harnessing TBGIs to induce upward regulatory races, as well as regulatory ratchets that prevent backsliding (Braithwaite and Drahos 2000, pp. 518-20). Our emphasis on the strength and breadth of regulatory standards, rather than their efficiency or optimality, reflects the fact that in most regulatory domains 'ordinary citizens want higher standards of regulatory protection than they get' (ibid., p. 609).

Turning to regulatory outcomes, for the reasons mentioned earlier we do not assess the degree to which TBGIs change the social or environmental performance of regulated actors. Rather, we address two lower-order outcomes: the uptake of standards by regulatory targets and synergies amongst regulatory regimes. Greater uptake contributes to participation and (all else equal) effectiveness, and can also be associated with other components of regulatory quality. Synergy can enhance responsiveness (contributing to a smart, sophisticated ensemble of regulatory instruments and actors), transparency (through consistency and coherence) and efficiency (through cost-effectiveness).

Some chapters discuss other regulatory outcomes - including changes in regulated actors' behaviour - and the social and environmental impacts that are the ultimate object of our inquiry. We consider this evidence in the Conclusion, but systematic attention to impacts remains beyond the scope of this book.

\subsubsection{Regulatory Capacity}

Regulatory quality can be examined at yet another level: regulatory capacity. This concept is absent from most accounts of regulatory quality, but has received substantial attention from other scholars of regulation and public policy. Like regulatory quality, regulatory capacity is the subject 
of diverse perspectives. We understand it as a multidimensional endowment of resources and capabilities that enable regulatory actors to pursue goals and that must be mobilized for regulatory systems to function. These resources and capabilities include material and symbolic resources, organizational capacity, networks, capacity for feedback and learning, and resilience to shocks.

Material resources include technology, equipment, supplies, physical facilities and finances. Symbolic resources include authority, legitimacy, information, knowledge, skill, expertise, motivation and commitment (Black 2003, pp. 73-6). Legitimacy is amongst the most valuable regulatory assets and determinants of regulatory quality (Baldwin and Cave 1999; Alemanno 2015). Organizational capacity has material and symbolic dimensions and includes leadership and management, governance and operational structures, problem-solving ability, physical and communication infrastructure, and inter-organizational linkages (Lusthaus et al. 2002; Black 2003, pp. 78-9).

Social networks also cut across the material-symbolic divide, enabling members to mobilize relational assets including visibility, reputation, expertise, reliability and trust, not to mention access to information, people, organizations and material resources (Gulati 2007; Smith and Fischlein 2010; Westerwinter, Chapter 7; Henriksen and Seabrooke, Chapter 8).

Entire agendas for governance reform, including adaptive management (Lee 1993) and experimentalist governance (Sabel and Zeitlin 2008), are built around capacity for feedback, learning and adaptation. Cycles of innovation, monitoring, evaluation, learning and revision are a common feature of many accounts of reflexive or responsive regulation (Lobel 2004, pp. 395-400). Ciara Brown and Colin Scott (2011, pp. 477-9) argue that learning capacity should be a criterion for regulatory quality.

Finally, resilience refers to an actor or institution's ability to adapt to, overcome and recover from exogenous shocks while maintaining essential functions and structures (Holling 1973; Underdal 2004, p. 30; Bourbeau 2018, p. 7). Like learning, it is a valuable regulatory capacity.

Different components of regulatory governance demand different capacities (Black 2003). Lack of capacity at any point along the governance chain can jeopardize the performance of a regulatory system (Wood et al. 2015, p. 357). Mobilizing the capacities of multiple actors and institutions is essential to regulatory governance. At a minimum, a regulator must have capacity to promulgate standards and a regulatory target must have capacity to implement them. Single actors seldom possess all the capacities necessary to achieve their regulatory goals or ensure the 
operation of a regulatory regime. An actor's ability to enrol the capacities of other actors, regimes or networks is thus crucial to the achievement of regulatory goals.

Our catalogue of regulatory capacities is partial and contestable. Other scholars propose different lists. Kenneth Abbott and Duncan Snidal (2009) identify four essential regulatory competencies: independence, representativeness, expertise and operational capacity. We include expertise and operational capacity, while capturing independence and representativeness in our discussion of regulatory quality. Julia Black's (2003, p. 73) six critical resources - information, expertise, financial and economic resources, authority and legitimacy, strategic position and organizational capacity — are also covered more or less by our account.

Regulatory capacity should be integrated into analyses of regulatory quality. Regulation cannot be effective, efficient, responsive, transparent, accountable or participatory if regulatory actors and institutions lack the capacity to make it so. This is most evident for effectiveness: organizations with greater material and symbolic resources tend to be more effective, while low-capacity organizations face greater challenges. But the point also applies to other dimensions of regulatory quality. Information, expertise, organizational capacity and networks help ensure regulatory efficiency. Responsiveness cannot be achieved without some resilience and learning capacity. Transparency, accountability and participation require material resources and organizational capacities.

The relation between capacity and quality is not unidirectional. Regulatory quality both depends upon and contributes to regulatory capacity. For example, a regulatory regime is more likely to attract wide participation if it already enjoys authority and legitimacy and is committed to transparency, accountability and participation. Wider participation in turn will further enhance the regime's authority, legitimacy and commitment. Likewise, more efficient regulation frees up resources to enhance the capacity of relevant actors and institutions, including targets. The literature on regulatory quality largely overlooks these connections to capacity (exceptions include Baldwin and Cave 1999; Brown and Scott 2011; Alemanno 2015). Yet regulatory quality and capacity are thoroughly intertwined. We therefore incorporate regulatory capacity into our investigation of regulatory quality, alongside outputs and outcomes.

\subsubsection{Marginalized Actors}

The second theme of the book is concerned with challenging disparities of power in transnational governance. Marginalized actors are actors who 
have little or no role in the creation and operation of regulatory governance institutions, or influence over regulatory outputs and outcomes. Unlike actors who periodically exchange positions and symbols of power through routine governance contests, marginalized actors are systematically disadvantaged. The purposes, structures and rules of governance disfavour their interests, shared understandings reinforce their disadvantage, and they appropriate few material and symbolic rewards (Fligstein and McAdam 2012, p. 13).

Marginalization is multidimensional and contextual. At the extreme, it includes those who are utterly excluded from the social contract (Santos 2002, p. 457), possibly including indigenous and stateless peoples, refugees, illegal immigrants, the disabled, migrant labourers, unskilled or unemployed workers, slum dwellers, landless peasants, subsistence producers and people living with addiction or mental illness. Marginalized actors can also occupy intermediate social positions, such as women, ethnic minorities, consumers, workers, LGBTQ+ people, and their advocates (Kiai 2014). Business actors can be marginalized if they occupy marginal positions in global supply chains, such as subsistence producers in developing countries. Civil society groups can be marginalized in some contexts, as where they interact with global corporations and powerful states, but not in others, as where elite Northern NGOs purport to represent constituents to whom they are not accountable. Actors identified as marginalized in this book include suppliers in developing countries, small-scale producers, peripheral East Asian state and market actors, public interest NGOs, industry-affected communities, workers and indigenous peoples. Ultimately, however, marginalized actors should define and speak for themselves (Cornwall 2004; Agyeman et al. 2009).

We do not define marginalized actors in terms of whether their cause is just. Such characterizations are inherently contestable, even if consensus might be possible in some cases. Moreover, actors with legitimate claims may have interests or values that clash; any choice between them is based on contestable normative commitments. Finally, there is no external touchstone for the public interest; social life always involves 'a combination of pecuniary interest-pursuit and citizenship', and actors' 'definitions of their self-interest are generally congealed with a vision of the appropriate social order' (Meidinger 1992, unpaginated; see also 1987, pp. 365-6). Everyone enters regulatory governance interactions 'from the perspective of one's own preferences that are always already partial and contested or contestable but striving for universal recognition' (Koskenniemi 2012, p. 320), and actors generally advance their preferences and interests via public-regarding discourse (Ayres and Braithwaite 1992, p. 59). 
Advancing marginalized actors can take weak and strong forms. In its weak form, it means harnessing TBGIs to better address marginalized actors' needs, mitigate adverse impacts on them, give them greater voice, and help them 'play' existing systems in their favour. These goals might be accomplished by, for example, increasing institutions' transparency, expanding participation and enhancing access to information (Gunningham et al. 1998, pp. 101-4). It might also include providing marginalized actors with resources to organize and participate effectively in regulatory governance (Ayres and Braithwaite 1992, pp. 18, 59). Such actions enable marginalized actors to get the most out of existing regulatory spaces, while expanding those spaces incrementally.

Such incremental advancement is the focus of this book. But the line between 'playing' the system and challenging it is blurry. Marginalized actors are always looking for cracks in the system, and routine contestation may shift imperceptibly to system rupture (Fligstein and McAdam 2012, pp. 97, 111). So we are also interested in the strong form of advancement: enhancing marginalized actors' chances to challenge and remake regulatory worlds. This entails developing skills and resources that enable marginalized actors to recognize when the limits of routine contention are reached; to fashion new conceptions that undermine existing regulatory settlements and attract wide support; to invent and deploy innovative regulatory forms; and to transform regulatory governance institutions or create new ones (ibid.).

Like regulatory quality, advancement of marginalized actors can be assessed at the level of regulatory capacities, outputs and outcomes. Thus we ask: Do TBGIs enhance marginalized actors' capacities to 'play the regulatory game' or to change the game? Do they enhance their material and symbolic resources? Do they improve their positions in regulatory networks, enhance their capacity for learning or increase their resilience? Do they lead regulatory institutions towards more participation, transparency and accountability? Do they produce regulatory standards that advance marginalized actors' interests and goals? And do they lead to regulatory outcomes that benefit marginalized actors?

\subsubsection{Linkages}

Enhancing regulatory quality and advancing marginalized actors are often aligned. Transparency, accountability and participation help marginalized actors, stave off capture by powerful actors, generate more regulatory options, provide information, strengthen standards and enhance effectiveness. Broader participation can enhance institutional legitimacy, an important regulatory capacity. And the more capacities marginalized 
actors can mobilize via networks, enrolment and other means, the better they can advance their interests. Most of the components of regulatory quality discussed in Part 3.1 are at least potentially consistent with advancing marginalized actors in the weak sense.

But regulatory quality and advancing marginalized actors are not always aligned. Enhanced regulatory capacity does not translate automatically into more ambitious standards, improved performance or greater protections. Efficiency and effectiveness can hamper marginalized actors' interests; broader participation can make regulatory processes more cumbersome and expensive. On the other hand, expanding marginalized voices often necessitates a more nuanced understanding of regulatory quality. Lowincome communities in developing countries, for example, are likely to insist on adequate schooling and alternative economic opportunities as part of a regulatory strategy to eliminate child labour. Small-scale producers might accept tougher environmental or social standards only if accompanied by technical and financial support or enhanced market access.

\subsection{PLAN OF THE BOOK}

\subsubsection{Overview}

The book's two main parts correspond to its two themes. Part I primarily emphasizes harnessing TBGIs to improve regulatory quality, while Part II highlights issues of power and marginalization. Part III contains a concluding chapter that draws out key theoretical and practical lessons. The chapters cover a variety of sectors and issue areas. Eleven address specific economic sectors: agriculture and food (Verbruggen and Havinga, Chapter 2; Casey, Chapter 9), energy (Paiement, Chapter 11; Bach, Chapter 12), finance (Winn, Chapter 5; Gao and Chen, Chapter 13), fisheries (Auld and Renckens, Chapter 6; Foley, Chapter 14), forestry (Carodenuto and Cashore, Chapter 10; Oman, Chapter 15) and sport (Schmidt, Chapter 4). The others examine multiple sectors (Westerwinter, Chapter 7; Henriksen and Seabrooke, Chapter 8) or cross-sectoral initiatives (Meidinger, Chapter 3; Wood, Chapter 16). Issue areas examined include climate change (Paiement, Bach), corporate social responsibility (Wood), tropical deforestation (Carodenuto and Cashore), derivatives trading (Gao and Chen), food safety (Verbruggen and Havinga; Casey), financial technology (Winn), indigenous rights (Oman), sustainable events (Schmidt) and supply chain management (Meidinger).

The chapters cover the entire six-by-six TBGI analytical matrix (Eberlein et al. 2014, p. 8). Table 1.1 summarizes this coverage. Like most 


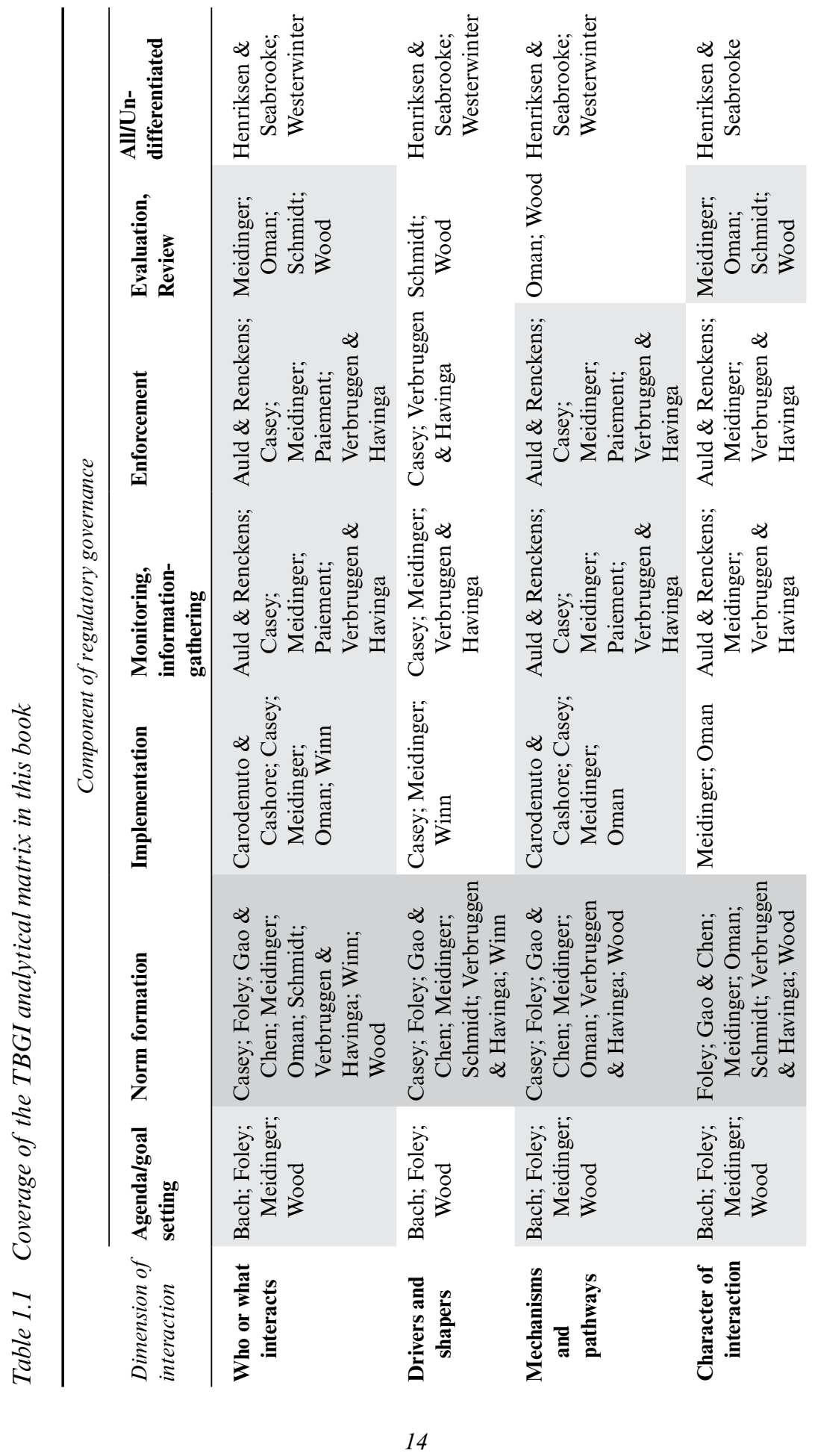



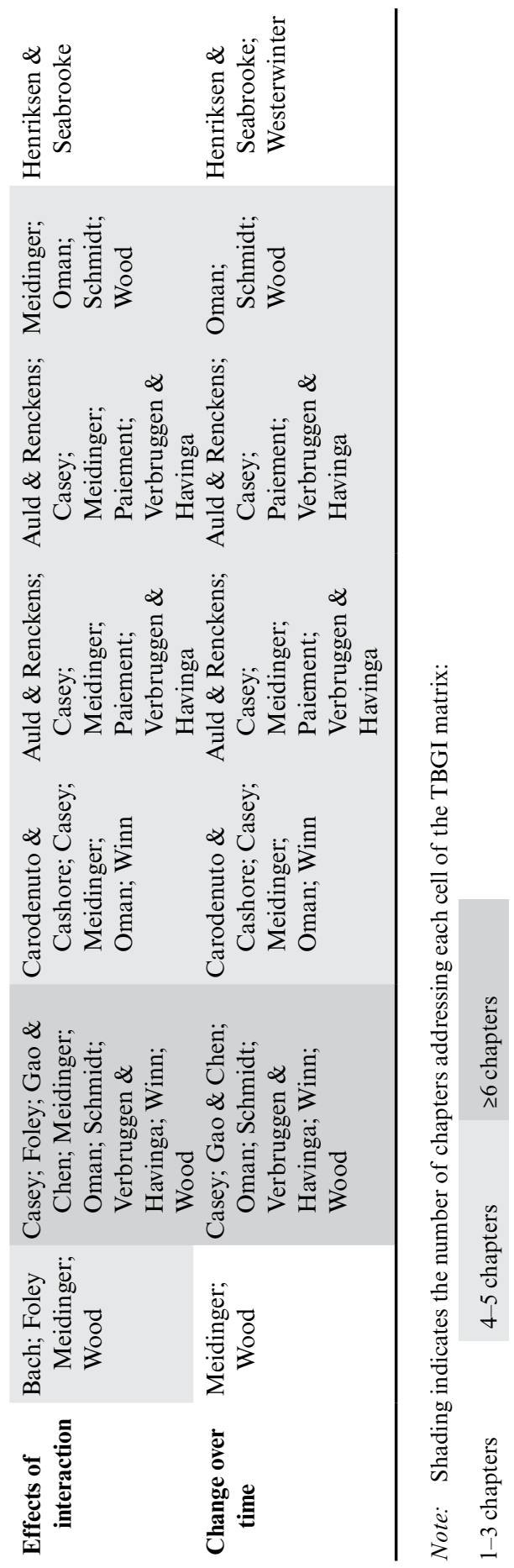
transnational governance research, they devote the greatest attention to norm formation, but agenda-setting, implementation, monitoring and enforcement also receive substantial treatment. The chapters analyse interactions involving numerous scales and units, ranging from individuals to entire social systems (Table 1.2).

\subsubsection{Part I: Improving the Quality of Transnational Regulation}

Part I opens on a cautiously optimistic note. Paul Verbruggen and Tetty Havinga (Chapter 2) explore interactions amongst the Global Food Safety Initiative (GFSI), transnational non-state food safety schemes and state actors in three countries. They argue that distributions of regulatory resources drive interactions, as actors seek to enrol one another's resources. Meta-regulator GFSI benchmarked non-state standards, which states recognized for enforcement purposes. These interactions raised standards, enhanced legitimacy for GFSI and benchmarked schemes, and improved state capacity. Yet mutual enrolment risks compromising enforcement agencies' independence.

Errol Meidinger (Chapter 3) explores interactions in sustainable supply chain management (SSCM). The main pathway of interaction is the supply chain; the main agent of interaction is the lead firm. Sustainability officers seek to enrol top management, cultivate direct supplier relationships and foster collaboration across supply chain tiers. The discourse is upbeat about these interactions, yet there is little evidence that they enhance regulatory capacities or improve standards.

Rebecca Schmidt (Chapter 4) examines sustainability standards for Olympic Games. She describes a process of cyclical regulation in which the International Olympic Committee (IOC) adopted rules for host city bids; prospective host cities proposed innovative environmental and social standards; the IOC incorporated these into its regulations; and subsequent aspiring host cities proposed further regulatory innovations. This cycle institutionalized local innovations as global standards and provided entry points for weaker actors.

Jane Winn (Chapter 5) presents a cautionary tale of failure to leverage TBGIs. EU regulators delegated the creation of the Single Euro Payments Area (SEPA) to banks, expecting them to fund the process. Banks resisted, and regulators ultimately reacted with a heavy hand, mandating use of SEPA for all payments. Winn argues that these interactions failed due to cognitive limitations. Regulators failed to recognize the public goods characteristics of proprietary payment systems, while banks systematically underestimated the magnitude of the costs and challenges posed by SEPA. 


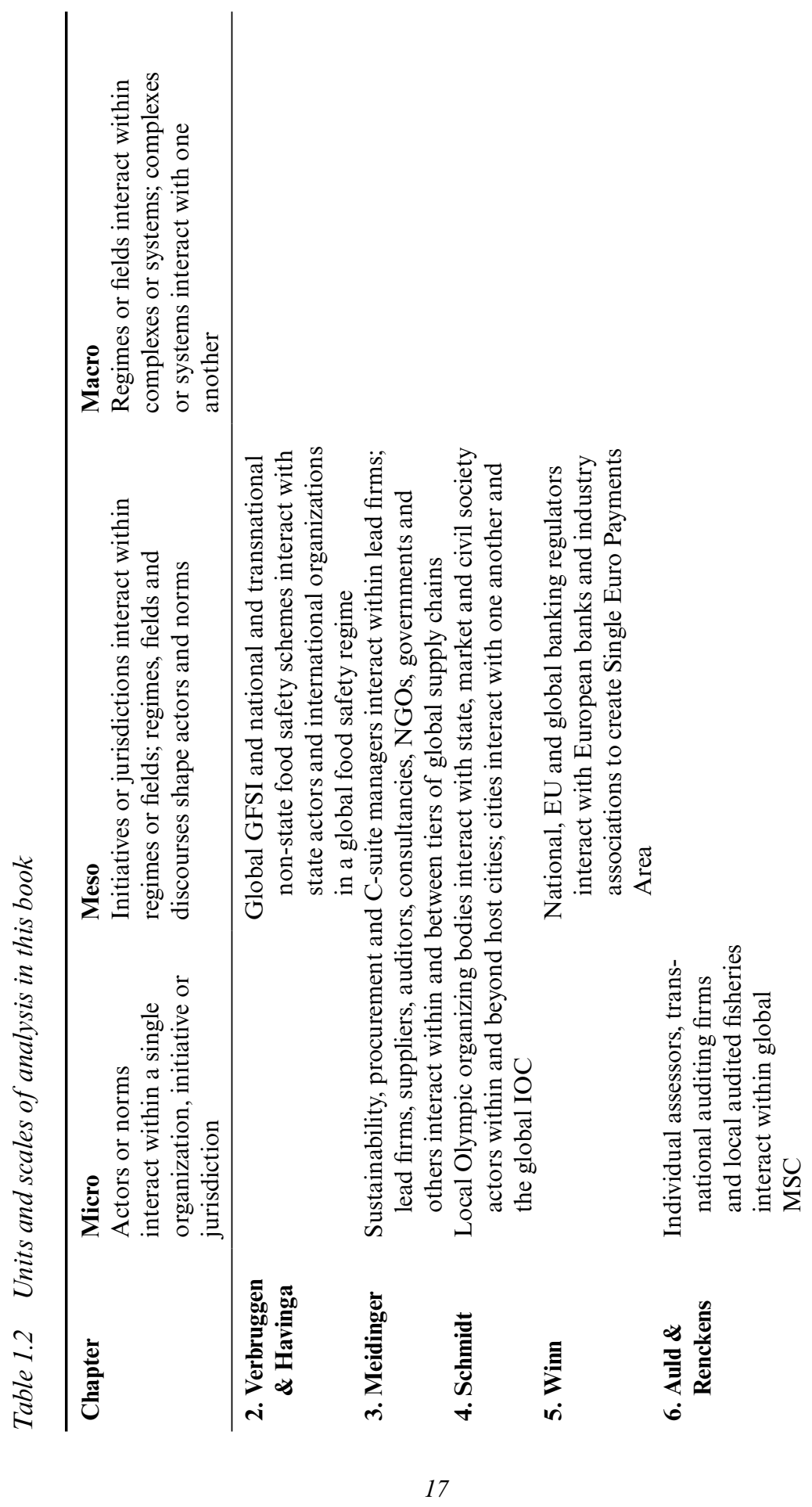




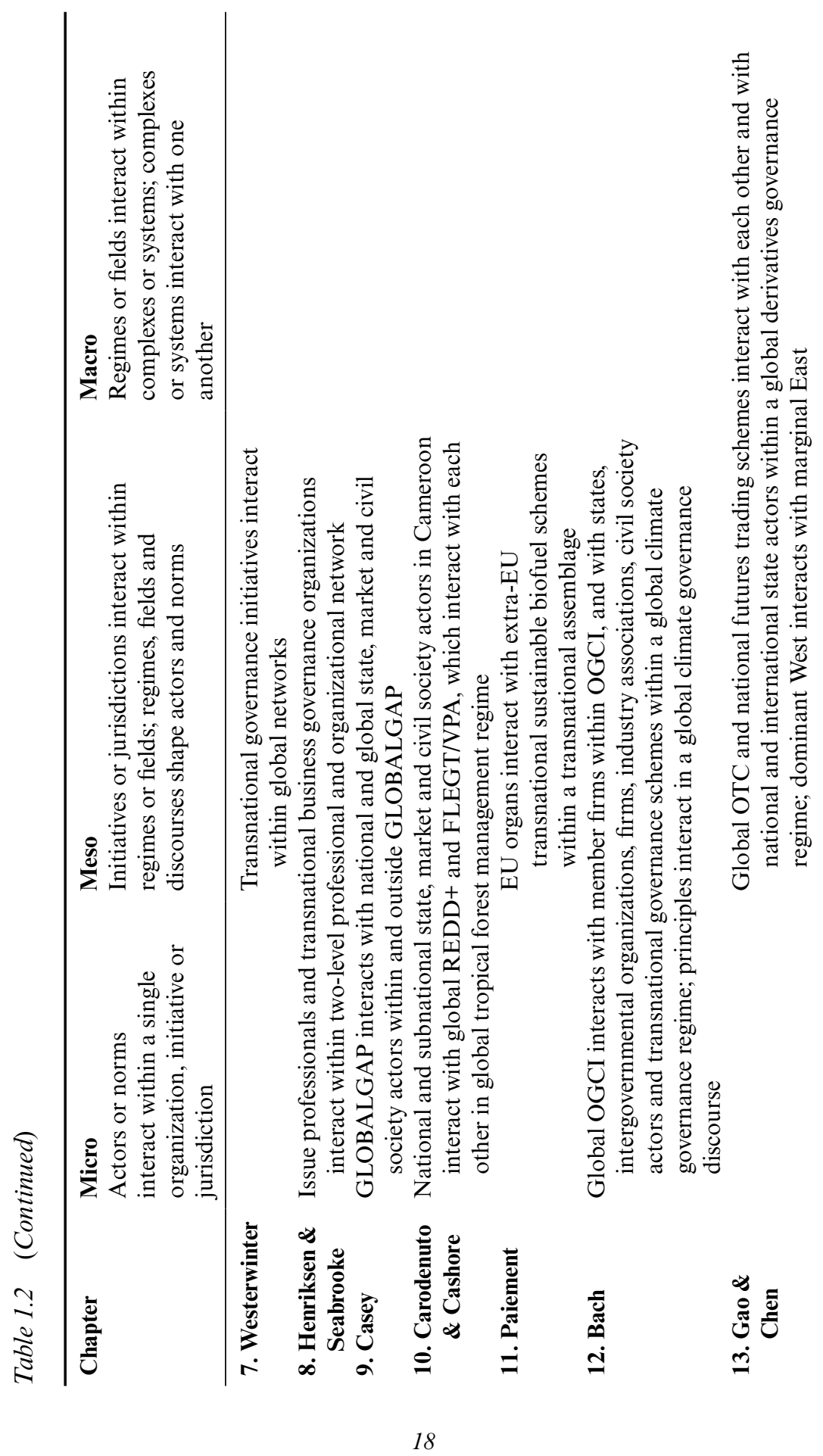




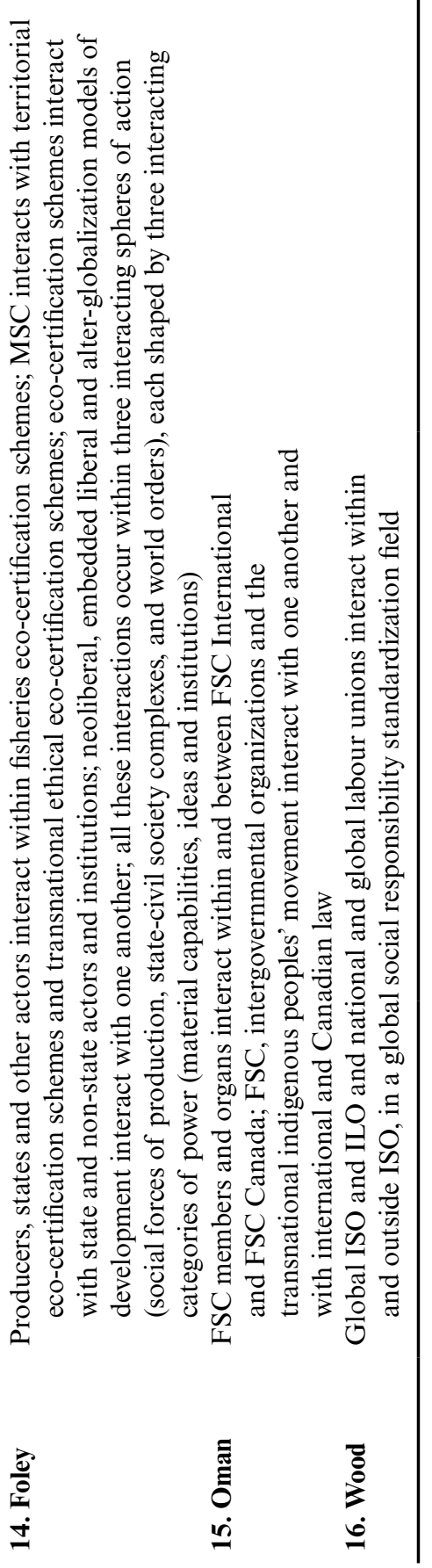


Graeme Auld and Stefan Renckens (Chapter 6) apply social network analysis to Marine Stewardship Council (MSC) audits, analysing interactions amongst 15 audit firms over 16 years. They find that firms compete on audit scores and duration, with equivocal implications for regulatory quality. Auld and Renckens also examine the mobility of individual assessors, which can diffuse knowledge and good practice, but can lead audit firms to free-ride on others' training expenditure and limit audit firms' independence.

Oliver Westerwinter (Chapter 7) uses social network analysis to explain increasing overlaps amongst transnational multi-stakeholder governance initiatives. He shows that overlaps amongst initiatives are highly uneven over time and across issue areas, driven by shared issue areas, large size, clustering and popularity. These findings suggest, amongst other things, that marginalized actors should concentrate advocacy efforts on large, focal schemes.

Lasse Folke Henriksen and Leonard Seabrooke (Chapter 8) argue that two-level networks of issue professionals and organizations impede better regulation and advancement of marginalized interests. Issue professionals network to gain control over important issues. This analysis helps explain how regulatory capacities are developed and distributed, and why efforts to harness TBGIs often falter.

\subsubsection{Part II: Advancing the Interests of Marginalized Actors}

Donal Casey (Chapter 9) begins Part II by documenting the negative impact of early institutionalization on transparency, accountability and empowerment in the field of food safety. He traces the growth of the GLOBALGAP farm assurance system from an informal retailers' initiative to a powerful global regulatory organization. Early interactions amongst retailers, producers and suppliers enabled big business to entrench a dominant position. Governments, NGOs and marginalized smallholders pressed GLOBALGAP to adopt more inclusive governance processes and standards, but early institutionalization limited the potential of these interactions.

Sophia Carodenuto and Ben Cashore (Chapter 10) examine TBGIs in the implementation of international policies for timber legality (FLEGT/ VPA) and avoidance of deforestation (REDD+) in Cameroon. These programs frustrated their own stated aim to empower local forestry operators and improve forest practices. International actors chose a complex, formal, technical approach that conflicted with their avowed choice of a logic of empowerment, thus excluding most Cameroonian forest operators and exacerbating governmental corruption and incapacity. 
Phillip Paiement (Chapter 11) presents another story of harnessing TBGIs to support empowerment in theory, but creating disempowerment in practice. The EU, seeking to promote biofuels while ensuring their sustainability, delegated monitoring and enforcement to voluntary schemes. It recognized 19 such schemes, but failed to assess their transparency. This triggered a proliferation of schemes, but a downward trend in participation, transparency and accountability, empowering agribusiness interests at the expense of marginalized communities.

Matthew Bach (Chapter 12) suggests that TBGIs steered by major oil companies might contribute to tackling climate change. He examines agenda-setting interactions amongst the Oil \& Gas Climate Initiative (OGCI), firms, industry associations and international organizations. He speculates that by endorsing a two-degree limit and promoting best practice, OGCI could trigger an upward regulatory ratchet, enrol powerful industry and interstate actors, and shift dialogue to a more proactive forum.

Simin Gao and Christopher Chen's (Chapter 13) analysis of TBGIs around financial derivatives trading focuses on responses by East Asian regulators and market operators to governance models exported from Western economies. The futures and over-the-counter (OTC) markets evolved separately, but each converged around a Western model through mimetic and normative isomorphism. After the global financial crisis, both regimes were disrupted by coercive isomorphism, consolidating Western dominance but generating some resistance by marginal Asian actors.

Paul Foley (Chapter 14) argues that the MSC's strained relationship with producers spurred the emergence of rival eco-certification schemes. Applying Robert Cox's (1987) critical international political economy, he argues that their counter-hegemonic potential is limited by a market-driven approach, large producers' entrenched advantage and international trade rules. New collaborations might overcome these constraints by shifting the MSC towards an embedded liberal model in which the state moderates market forces, or by building a more radical bottom-up coalition amongst fishery workers and transnational economic actors.

Natalie Oman (Chapter 15) is more sanguine about harnessing TBGIs. She documents an iterative process of interaction amongst the FSC, international law and national law around the norm of indigenous peoples' free, prior and informed consent (FPIC). Indigenous advocates leveraged the FSC's inclusive governance structure, interactions between its international and Canadian organs, and international human rights law to strengthen FPIC standards in the FSC. This opened an avenue 
towards a de facto consent power over forestry projects in Canada, and a stronger FPIC rule in customary international law.

Finally, Stepan Wood (Chapter 16) shows that despite being marginalized in the International Organization for Standardization (ISO), organized labour achieved remarkably favourable results in ISO 26000. He explains these interactions in terms of regulatory legitimation and enrolment. Organized labour overcame more powerful adversaries by leveraging the uneasy relationship between ISO, with a legitimacy 'deficit', and the International Labour Organization, which could enhance ISO's legitimacy. He proposes a triadic strategy through which marginalized actors can exploit such legitimacy differentials.

Overall, the chapters paint a decidedly mixed picture of the ability of TBGIs to improve regulatory quality and advance marginalized interests. Only five chapters find positive effects on one or both of those goals. In three chapters, TBGIs advanced both regulatory quality and marginalized actors' interests: Schmidt (Chapter 4), Oman (Chapter 15) and Wood (Chapter 16). Two chapters identify improvements in regulatory quality alone: Verbruggen \& Havinga (Chapter 2) and Bach (Chapter 12); Westerwinter (Chapter 7) also suggests how TBGIs might improve regulatory quality. The remaining chapters find (or predict) mixed, unclear or negative effects. We explore these findings in more detail in the Conclusion.

\section{REFERENCES}

Abbott, Kenneth W., Philipp Genschel, Duncan Snidal and Bernhard Zangl (eds) (2015), International Organizations as Orchestrators, Cambridge, UK: Cambridge University Press.

Abbott, Kenneth W. and Duncan Snidal (2009), 'The governance triangle: regulatory standards institutions and the shadow of the state', in Walter Mattli and Ngaire Woods (eds), The Politics of Global Regulation, Princeton, NJ: Princeton University Press, pp. 44-88.

Agyeman, Julian, Peter Cole, Randolph Haluza-DeLay and Pat O'Riley (eds) (2009), Speaking for Ourselves: Environmental Justice in Canada, Vancouver: UBC Press.

Alemanno, Alberto (2015), 'How much better is better regulation: assessing the impact of the better regulation package on the European Union: a research agenda', European Journal of Risk Regulation, 6, 344-56.

Alter, Karen J. and Sophie Meunier (2009), 'The politics of international regime complexity', Perspectives on Politics, 7 (1), 13-24.

Andenas, Mads and Eirik Bjorge (eds) (2015), A Farewell to Fragmentation: Reassertion and Convergence in International Law, Cambridge, UK: Cambridge University Press.

Ayres, Ian and John Braithwaite (1992), Responsive Regulation: Transcending the Deregulation Debate, Oxford and New York: Oxford University Press. 
Bache, Ian and Matthew V. Flinders (eds) (2004), Multi-Level Governance, Oxford: Oxford University Press.

Baldwin, Robert and Julia Black (2008), 'Really responsive regulation', Modern Law Review, 71, 59-94.

Baldwin, Robert and Martin Cave (1999), Understanding Regulation: Theory, Strategy, and Practice, Oxford and New York: Oxford University Press.

Bartley, Tim (2014), 'Transnational governance and the re-centered state: sustainability or legality?' Regulation and Governance, 8 (1), 93-109.

Berman, Paul Schiff (2012), Global Legal Pluralism: A Jurisprudence of Law Beyond Borders, New York: Cambridge University Press.

Black, Julia (2002), 'Regulatory conversations', Journal of Law and Society, 29 (1), 163-96.

Black, Julia (2003), 'Enrolling actors in regulatory systems: examples from UK financial services regulation', Public Law, 63-91.

Blome, Kerstin, Andreas Fischer-Lescano, Hannah Franzki, Nora Markard and Stefan Oeter (eds) (2016), Contested Regime Collisions: Norm Fragmentation in World Society, Cambridge, UK: Cambridge University Press.

Bourbeau, Philippe (2018), On Resilience: Genealogy, Logics, and World Politics, New York: Cambridge University Press.

Braithwaite, John and Peter Drahos (2000), Global Business Regulation, Cambridge, UK: Cambridge University Press.

Brown, Ciara and Colin Scott (2011), 'Regulation, public law, and better regulation', European Public Law, 17 (3), 467-84.

Calliess, Gralf-Peter and Peer Zumbansen (2010), Rough Consensus and Running Code: A Theory of Transnational Private Law, Oxford and Portland, OR: Hart.

Cashore, Benjamin, Graeme Auld and Deanna Newsom (2004), Governing through Markets: Forest Certification and the Emergence of Non-State Authority, New Haven, CT: Yale University Press.

Cornwall, Andrea (2004), 'Spaces for transformation? Reflections on issues of power and difference in participation in development', in Samuel Hickey and Giles Mohan (eds), Participation: From Tyranny to Transformation?, London: Zed Books, pp. 75-91.

Cox, Robert W. (1987), Production, Power, and World Order: Social Forces in the Making of History, New York: Columbia University Press.

Cutler, A. Claire, Virginia Haufler and Tony Porter (1999), Private Authority and International Affairs, Albany: State University of New York Press.

Dingwerth, Klaus (2007), The New Transnationalism: Transnational Governance and Democratic Legitimacy, Basingstoke, UK and New York: Palgrave Macmillan.

Easton, David (1965), A Systems Analysis of Political Life, New York: Wiley.

Eberlein, Burkard, Kenneth W. Abbott, Julia Black, Errol Meidinger and Stepan Wood (2014), 'Transnational business governance interactions: conceptualization and framework for analysis', Regulation and Governance, 8 (1), 1-21.

Edelenbos, Jurian and Ingmar van Meerkerk (2016), 'Introduction: three reflecting perspectives on interactive governance', in Jurian Edelenbos and Ingmar van Meerkerk (eds), Critical Reflections on Interactive Governance: Self-Organization and Participation in Public Governance, Cheltenham, UK and Northampton, MA, USA: Edward Elgar, pp. 1-28.

Esty, Daniel C. and Damien Geradin (eds) (2001), Regulatory Competition and Economic Integration, Oxford: Oxford University Press.

European Commission (2001), Mandelkern Group on Better Regulation Final Report, 13 November, Brussels: European Commission. 
European Commission (2002), 'Action plan "simplifying and improving the regulatory environment"' (Communication) COM (2002) 278 final.

European Commission (2017), 'Better regulation guidelines', 7 July (Commission Staff Working Document) SWD (2017) 350.

Fligstein, Neil and Doug McAdam (2012), A Theory of Fields, Oxford and New York: Oxford University Press.

Fransen, Luc (2011), 'Why do private governance organizations not converge? A political-institutional analysis of transnational labor standards regulation', Governance, 24 (2), 359-87.

Gehring, Thomas and Sebastian Oberthür (2009), 'The causal mechanisms of interaction between international institutions', European Journal of International Relations, 15 (1), 125-56.

Gulati, Ranjay (2007), Managing Network Resources: Alliances, Affiliations and Other Relational Assets, Oxford: Oxford University Press.

Gunningham, Neil, Peter N. Grabosky and Darren Sinclair. (1998), Smart Regulation: Designing Environmental Policy, Oxford: Clarendon Press.

Hahn, Robert W. and Roger G. Noll (1983), 'Barriers to implementing tradable air pollution permits: problems of regulatory interactions', Yale Journal on Regulation, 1, 63-92.

Hale, Thomas and David Held, (2011), Handbook of Transnational Governance: Institutions and Innovations, Cambridge, UK and Malden, MA: Polity.

Halliday, Terence C. and Gregory Shaffer (2015), 'Transnational legal orders', in Terence C Halliday and Gregory Shaffer (eds), Transnational Legal Orders, New York: Cambridge University Press, pp. 1-72.

Holling, C.S. (1973), 'Resilience and stability of ecological systems', Annual Review of Ecology and Systematics, 4, 14.

Hood, Christopher, Henry Rothstein and Robert Baldwin (2001), The Government of Risk: Understanding Risk Regulation Regimes, Oxford: Oxford University Press.

Hooghe, Liesbet and Gary Marks (eds) (2001), Multi-Level Governance and European Integration, Lanham, MD: Rowman \& Littlefield.

Jessup, Philip C. (1956), Transnational Law. Storrs Lectures on Jurisprudence, New Haven, CT: Yale University Press.

Keck, Margaret E. and Kathryn Sikkink (1998), Activists Beyond Borders: Advocacy Networks in International Politics, Ithaca, NY: Cornell University Press.

Keohane, Robert O. and Joseph S. Nye (1971), Transnational Relations and World Politics, Cambridge, MA: Harvard University Press.

Kiai, Maina (2014), Report of the Special Rapporteur on the Rights to Freedom of Peaceful Assembly and of Association, Maina Kiai, to the Human Rights Council, April, A/HRC/26/29.

Kooiman, Jan (2003), Governing as Governance, London: Sage.

Koskenniemi, Martti (2012), 'Hegemonic regimes', in Margaret A. Young (ed.), Regime Interaction in International Law: Facing Fragmentation, Cambridge, UK: Cambridge University Press, pp. 305-24.

Labory, Sandrine and Marco Malgarini (2000), 'Regulation in Europe: justified burden or costly failure?' in Giampaolo Galli and Jacques Pelkmans (eds) Regulatory Reform and Competitiveness in Europe, Volume I: Horizontal Issues, Cheltenham, UK and Northampton, MA, USA: Edward Elgar, pp. 81-126.

Lee, Kai N. (1993), Compass and Gyroscope: Integrating Science and Politics for the Environment, Washington, DC: Island Press. 
Likosky, Michael (ed.) (2002), Transnational Legal Processes: Globalisation and Power Disparities, London: Butterworths.

Lobel, Orly (2004), 'The renew deal: the fall of regulation and the rise of governance in contemporary legal thought', Minnesota Law Review, 89, 342-470.

Lusthaus, Charles, Marie-Hélène Adrien, Gary Anderson, Fred Carden and George Plinio Montalván (2002), Organizational Assessment: A Framework for Improving Performance, Washington, DC and Ottawa: Inter-American Development Bank and International Development Research Centre.

Meidinger, Errol (1987), 'Regulatory culture: a theoretical outline', Law \& Policy, $9(4), 355-86$.

Meidinger, Errol (1992), 'Administrative regulation and democracy', Baldy Center for Law and Social Policy Working Paper, State University of New York at Buffalo, accessed 12 April 2019 at http://web2.law.buffalo.edu/faculty/meidinger/ scholarship/regdem.html.

Oberthür, Sebastian and Thomas Gehring (eds) (2006), Institutional Interaction in Global Environmental Governance: Synergy and Conflict among International and EU Rules, Cambridge, MA: MIT Press.

Oberthür, Sebastian and Olav Schram Stokke (eds) (2011), Managing Institutional Complexity: Regime Interplay and Global Environmental Change, Cambridge, MA: MIT Press.

OECD (1995), Recommendation of the Council of the OECD on Improving the Quality of Government Regulation (Adopted on 9 March 1995) Including the OECD Reference Checklist for Regulatory Decision-Making and Background Note, OCDE/GD(95) 95 .

OECD (2005), OECD Guiding Principles for Regulatory Quality and Performance, Paris: OECD.

Ogus, Anthony (1995), 'Quality control for European regulation', Maastricht Journal of European and Comparative Law, 2, 325-38.

Osborne, David and Ted Gaebler (1992), Reinventing Government: How the Entrepreneurial Spirit Is Transforming the Public Sector, Reading, MA: Addison-Wesley.

Overdevest, Christine (2010), 'Comparing forest certification schemes: the case of ratcheting standards in the forest sector', Socio-Economic Review, 8, 47-76.

Pelkmans, Jacques, Sandrine Labory and Giandomenico Majone (2000), 'Better EU regulatory quality: assessing current initiatives and new proposals', in Giampaolo Galli and Jacques Pelkmans (eds), Regulatory Reform and Competitiveness in Europe, Volume I: Horizontal Issues, Cheltenham, UK and Northampton, MA, USA: Edward Elgar, pp. 461-526.

Radaelli, Claudio M. and Fabrizio De Francesco (2007), Regulatory Quality in Europe: Concepts, Measures and Policy Processes, Manchester: Manchester University Press.

Raustiala, Kal and David G. Victor (2004), 'The regime complex for plant genetic resources', International Organization, 58 (2), 277-309.

Risse-Kappen, Thomas (ed.) (1995), Bringing Transnational Relations Back In: Non-State Actors, Domestic Structures and International Institutions, Cambridge, UK: Cambridge University Press.

Sabel, Charles F. and Jonathan Zeitlin (2008), 'Learning from difference: the new architecture of experimentalist governance in the EU', European Law Journal, 14 (3), 271-327.

Santos, Boaventura de Sousa (2002), Toward a New Legal Common Sense: Law, Globalization and Emancipation, 2nd edn, London: Butterworths. 
Schapiro, Robert A. (2006), 'From dualist federalism to interactive federalism', Emory Law Journal, 56 (1), 1-18.

Scott, Colin (2004), 'Regulation in the age of governance: the rise of the postregulatory state', in Jacint Jordana and David Levi-Faur (eds), The Politics of Regulation: Institutions and Regulatory Reforms for the Age of Governance, Cheltenham, UK and Northampton, MA, USA: Edward Elgar, pp. 145-74.

Scott, Colin, Fabrizio Cafaggi and Linda Senden (2011), 'The conceptual and constitutional challenge of transnational private regulation', Journal of Law and Society, 38 (1), 1-19.

Smith, Timothy M. and Miriam Fischlein (2010), 'Rival private governance networks: competing to define the rules of sustainability performance', Global Environmental Change, 20, 511-22.

Tamanaha, Brian Z. (2001), A General Jurisprudence of Law and Society, Oxford: Oxford University Press.

Twining, William (2009), General Jurisprudence: Understanding Law from a Global Perspective, Cambridge, UK: Cambridge University Press.

Underdal, Arild (2004), 'Methodological challenges in the study of regime effectiveness', in Arild Underdal and Oran R. Young (eds), Regime Consequences: Methodological Challenges and Research Strategies, Dordrecht, Netherlands: Kluwer Academic Publishers, pp. 27-48.

Underdal, Arild and Oran R. Young (eds) (2004), Regime Consequences: Methodological Challenges and Research Strategies, Dordrecht, Netherlands: Kluwer Academic Publishers.

Wood, Stepan, Kenneth W. Abbott, Julia Black, Burkard Eberlein and Errol Meidinger (2015), 'The interactive dynamics of transnational business governance: a challenge for transnational legal theory', Transnational Legal Theory, 6 (2), 333-69.

World Bank (2016), Doing Business 2016: Measuring Regulatory Quality and Efficiency, Washington, DC: World Bank Group.

Young, Margaret A. (ed.) (2012), Regime Interaction in International Law: Facing Fragmentation, Cambridge, UK: Cambridge University Press.

Young, Oran R. (2002), The Institutional Dimensions of Environmental Change: Fit, Interplay, and Scale, Cambridge, MA: MIT Press.

Young, Oran R. (2017), Governing Complex Systems: Social Capital for the Anthropocene, Cambridge, MA: MIT Press. 